\title{
ANALISIS FAKTOR-FAKTOR YANG MEMPENGARUHI STRUKTUR MODAL PADA PERUSAHAAN MAKANAN DAN MINUMAN YANG TERDAFTAR DI BURSA EFEK INDONESIA PADA TAHUN 2008 -2015
}

\author{
Anthony Ghozali \\ Program Studi Magister Manajemen Universitas Tarumanagara \\ ga262617@gmail.com \\ Ignatius Roni Setyawan \\ Program Studi Magister Manajemen Universitas Tarumanagara
}

\begin{abstract}
Capital structure is one of the most important things that every company should concern about. As alongwith economic issues that recently happened in this past years, such as crisis, inflation, etc, this study aims to find out about the factors that affect the capital structure in the food and beverage sectors listed in the Indonesia Stock Exchange (BEI) in the year of 2008-2015. The data sample of 8 companies is collected by using financial statements from each company that issued by Indonesia Stock Exchange.. This study use multiple regression with Ordinary Least Square (OLS) method to examine the effect of profitability (return on asset), firm size, asset growth and liquidity on the capital structure (debt-to-equity ratio). The conclusion of this study indicate that profitability, firm size, asset growth and liquidity affect the capital structure simultaneously, meanwhile partially, profitability affect the capital structure while firm size, asset growth and liquidity not affect the capital structure.
\end{abstract}

Keywords : Capital Structure, Profitability, Firm Size, Asset Growth, Liquidity.

\section{Latar Belakang Masalah}

Seluruh perusahaan yang ada terutama di Indonesia berlomba untuk memperoleh laba semaksimal mungkin dengan biaya yang minimal sesuai dengan tujuan perusahaan, hal ini tidak terlepas dari kondisi perekonomian di Indonesia yang saat ini semakin maju dan berkembang, tetapi seiring dengan perkembangan tersebut tidak terlepas dari masalah ekonomi yang ada pada saat ini. Perkembangan pada sektor industri makanan dan minuman di Indonesia salah satunya, dimana pada sector industry tersebut mengalami pertumbuhan perusahaan yang sangat pesat. Industri makanan dan minuman ini menarik karena merupakan salah satu sektor industri yang dapat bertahan di tengah kondisi perekonomian yang dialami Indonesia yang sempat lesu akibat dari krisis. Masalah utama saat ini yang dialami perusahaan makanan dan minuman saat ini adalah ketersediaan bahan baku impor.

Seperti yang diketahui, masalah ekonomi yang paling utama yang sedang dihadapi oleh perusahaan di Indonesia adalah krisis dan inflasi. Krisis pada tahun 2008 yang terjadi akibat dari kredit macet di Amerika dan menyebar ke negara-negara lain memberikan dampak yang cukup besar terhadap perusahaan-perusahan di Indonesia. Perusahaan-perusahaan di Indonesia masih cukup bergantung pada dana asing, akan tetapi akibat dari krisis tersebut, banyak investor asing yang menarik dananya dari Indonesia, sehingga menyebabkan perusahaan cukup kesulitan untuk menutupi biaya yang ada dan tentunya mempengaruhi struktur keuangan perusahaan khususnya struktur modal. Selain itu akibat dari inflasi yang terjadi, perusahaan-perusahaan di Indonesia harus mengeluarkan biaya operasional yang lebih besar seiring dengan 
besarnya inflasi tiap tahunnya. Perusahaan harus mempertimbangkan system pendanaan yang akan digunakannya guna mempertahankan keberlangsungan perusahaan. Pengelolaan struktur keuangan perusahaan harus dilakukan untuk menghindari kemungkinan financial distress. Struktur keuangan perusahaan terdiri atas modal eksternal (utang) dan modal internal (ekuitas).

Struktur keuangan perusahaan yang menggambarkan susunan keseluruhan sisi kredit neraca yang terdiri atas utang jangka pendek, utang jangka panjang, dan modal sendiri (Margaretha, 2007). Dana yang dimaksud dapat diperoleh dari sumber internal dan eksternal perusahaan. Menurut Sunder dan Myers (1994), perusahaan lebih baik menggunakan pendanaan yang berasal dari dalam perusahaan (sumber internal) dibandingkan dengan pendanaan yang berasal dari luar perusahaan (sumber eksternal), karena semakin banyaknya pendanaan dari luar perusahaan akan mengakibatkan kewajiban yang harus dipenuhi perusahaan bertambah dan memperbesar resiko perusahaan mengalami financial distress.

Penelitian ini bertujuan untuk mengetahui keputusan pendanaan yang paling baik yang dapat digunakan perusahaan makanan dan minuman kaitannya dengan struktur modal perusahaan dalam menghadapi permasalahan ekonomi yang timbul saat ini, selain itu untuk mengetahui apa saja yang dapat mempengaruhi struktur modal pada perusahaan makanan dan minuman.

\section{Kerangka Teoritis}

Pecking Order Theory diperkenalkan pertama kali oleh Donaldson pada tahun 1961. Sistem pendanaan diawali dengan laba ditahan, kemudian utang dan yang terakhir dengan penerbitan saham. Ketika seorang manajer suatu akan melakukan pendanaan suatu proyek yang pertama kali digunakan sebagai modal operasionalnya adalah laba ditahan. Jika dari modal internal tidak mencukupi untuk membiayai investasi, maka manajer akan meningkatkan pembiayaan eksternal melalui utang. Bila pendanaan dari utang juga tidak mencukupi modal yang dibutuhkan, perusahaan menerbitkan saham baru yang merupakan pilihan terakhir para manajer (Gitman dan Zutter, 2012).

Teori ini menunjukkan konsistensi fakta - fakta mengenai keputusan pembiayaan perusahaan. Pertama, sebagian besar dari investasi baru akan didanai menggunakan modal internal, yaitu laba ditahan, seiring dengan berjalannya investasi tersebut, perusahaan meningkatkan pendanaan eksternalnya. Kedua, perusahaan meningkatkan utang dengan frekuensi yang lebih besar dari modal seperti yang diprediksi teori pecking order. Ketiga, terdapat kecenderungan bagi perusahaan yang menghasilkan laba cukup besar untuk berhutang lebih sedikit dibandingkan dengan perusahaan yang menhasilkan laba lebih sedikit (Gitman dan Zutter, 2012).

Capital Structure menurut Brealey, Myers, dan Marcus (2007) Capital structure adalah gabungan pendanaan dari utang jangka panjang dan ekuitas. Capital structure suatu perusahaan merupakan pembiayaan permanen perusahaan yang terdiri dari utang jangka panjang dan modal sendiri (Margaretha, 2007). Menurut Weston dan Brigham (1993), Struktur modal adalah hasil atau akibat dari keputusan pendanaan yang intinya memilih apakah menggunakan utang atau ekuitas untuk mendanai operasi perusahaan.

Profitability Menurut Brigham dan Houston (2009) profitabilitas adalah sekelompok rasio yang memperlihatkan pengaruh gabungan dari likuiditas, manajemen aktiva, dan utang terhadap hasil aktiva. Gitman dan Zutter (2012) 
mendefinisikan profitabilitas sebagai hubungan antara pendapatan dan biaya-biaya yang dihasilkan perusahaan dengan penggunaan aset baik aset lancar maupun aset tetap dalam aktivitas produksi.

Firm Size ukuran perusahaan menggambarkan besar kecilnya suatu perusahaan. Besar kecilnya perusahaan dapat ditinjau dari lapangan usaha yang dijalankan. Penentuan besar kecilnya skala perusahaan dapat ditentukan berdasarkan total penjualan, total aktiva (Seftianne dan Handayani, 2011). Firm size dapat menjadi gambaran prospek perusahaan ke depan dilihat dari total aset yang dimiliki perusahaan yang mampu memberikan tanda bahwa perusahaan dengan total asset yang besar akan memiliki prospek yang baik. (Ismiyanti dan Armansyah, 2010)

Growth menurut Brigham dan Houston (2009) pertumbuhan aset perusahaan merupakan salah satu faktor yang dipertimbangkan dalam struktur modal perusahaan. Hal ini disebabkan tingkat pertumbuhan yang signifikan, karena itu pilihan sumber pendanaan tidak akan menjadi permasalahan bagi perusahaan. Pertumbuhan perusahaan dapat dilihat dari total nilai asset yang dimiliki perusahaan. Menurut Titman dan Wessels (1988) kesempatan pertumbuhan merupakan modal aset yang menambah nilai bagi perusahaan. Loof (2003) menyimpulkan pertumbuhan aset adalah perubahan aset dari tahun sebelumnya untuk tahun berjalan.

Liquidity menurut Brigham dan Houston (2009) likuiditas merupakan aset perusahaan yang dapat diperdagangkan di pasar aktif dan dapat dikonversi menjadi kas pada harga pasar yang berlaku dalam waktu yang cepat dan menggambarkan kemampuan perusahaan dalam memenuhi kewajiban (utang) jangka pendek.

\section{Tinjauan Pustaka}

Penelitian Titman dan Wessels (1988) menggunakan sampel sebanyak 469 perusahaan manufaktur di Amerika Serikat periode 1974-1982, data diperoleh dari U.S Departement of Labor, Bureau of Labor Statistics. Variabel independen yang digunakan adalah collateral value, non-debt tax shields, future growth, uniquenes, size, volatility, and profitability serta variabel dependennya adalah capital structure. Hasil penelitian tersebut menunjukkan bahwa non debt tax shield, collateral value, volatility dan future growth tidak bepengaruh terhadap capital structure sedangkan uniquenes, size, volatility, and profitability memiliki pengaruh negatif terhadap capital structure.

Seftianne dan Handayani (2011) menggunakan perusahaan publik sektor manufaktur dalam penelitiannya. Sampel terdiri dari 92 data perusahaan dengan periode 2007-2009 yang terdaftar di Bursa Efek Indonesia dengan metode purposive sampling. Variabel independennya adalah growth opportunity, size, managerial ownership, business risk, profitability, liquidity dan asset structure sedangkan variabel dependennya adalah capital structure. Hasilnya adalah growth opportunity dan size mempengaruhi capital structure sedangkan managerial ownership, business risk, profitability, liquidity dan asset structure tidak mempengaruhi capital structure.

Nishioka dan Baba (2004) melakukan penelitian pada perusahaan di Jepang sebanyak 700 perusahaan yang terdaftar di Bursa Efek Tokyo sejak awal 1990-an. Variabel independennya adalah equity cost, debt cost, volatility firm value, tangible asset, firm size, profitability, market to book ratio. Hasil penelitian adalah equity cost dan debt cost memiliki pengaruh signifikan. Volatility firm value, profitability, firm size, tangible asset, dan market to book ratio berpengaruh signifikan negatif terhadap capital structure.

\section{Hipotesis}


Hipotesis 1 :profitability (return on asset), firm size, growth (asset growth) dan liquidity secara bersama-sama mempengaruhi capital structure pada tahun 2008-2015 Hipotesis 2 : Profitability (return on asset) mempengaruhi capital structure pada tahun 2008-2015

Hipotesis 3 : Firm size mempengaruhi capital structure pada tahun 2008-2015

Hipotesis 4 : Growth (asset growth) mempengaruhi capital structure pada tahun 2008-2015

Hipotesis 5 : Liquidity mempengaruhi capital structure pada tahun 2008-2015

\section{Metodologi Penelitian}

Populasi pada penelitian ini adalah seluruh perusahaan yang terdaftar di Bursa Efek Indonesia (BEI) dan sampel pada penelitian ini adalah perusahaan makanan dan minuman yang terdaftar di Bursa Efek Indonesia (BEI). Metode pemilihan sampel menggunakan metode purposive sampling. Dari perusahaan-perusahaan industri makanan dan minuman yang terdaftar di Bursa Efek Indonesia (BEI) pada periode 2008-2015 dan diambil delapan sampel yang memenuhi ketentuan tersebut.

Data dari delapan perusahaan yang dijadikan sampel diperoleh dari laporan keuangan tahun 2008 sampai dengan tahun 2015. Penelitian ini menggunakan persamaan regresi linier berganda dengan metode Ordinary Least Square (OLS) yang didapatkan dari hasil output Eviews 9.

\section{Operasionalisasi Variabel}

Data tiap variabel dalam penelitian ini menggunakan rasio-rasio keuangan yang telah rangkum dalam tabel sebagai berikut :

\section{Tabel 3.1}

Operasionalisasi Variabel

\begin{tabular}{|c|c|}
\hline Variabel & Indikator \\
\hline Profitability & Net Income \\
\hline & $R U A=\overline{\text { Total Asset }}$ \\
\hline Firm Size & $F Z=$ Ln Total Asset \\
\hline Asset Growth & Total Asset $_{t}-$ Total Asset $_{t-1}$ \\
\hline Liquidity & $C R=\frac{\text { Turrent Assets }_{t-1}}{\text { Current Liabilities }}$ \\
\hline
\end{tabular}

\section{Analisis Regresi Linier Berganda}

Analisis regresi digunakan untuk menguji hipotesis yaitu hipotesis pertama sampai dengan hipotesis keempat dengan variabel independennya adalah profitability, firm size, asset growth, dan liquidity. Model regresi berganda sebagai berikut :

\section{DER $=1,583886-2,365810$ ROA $-0,018756$ FZ + 0.0182841 AG - 0,067878 CR}

Persamaan regresi berganda pada tahun 2008-2015, memiliki pengertian bahwa debt to total equity (DER) akan bernilai 1,583886 satuan jika variabel independen sama dengan nol. Jika terjadi kenaikan satu satuan pada return on asset dan variabel independen yang lain konstan, maka debt to total equity akan turun sebesar 2,365810 satuan. Jika terjadi kenaikan satu satuan pada firm size dan variabel independen yang lain konstan, maka debt to total equity akan turun sebesar 0,018756 satuan. Jika terjadi kenaikan satu satuan pada asset growth dan variabel independen yang lain konstan, maka debt to total equity akan naik sebesar 0,182841 satuan. Jika terjadi 
kenaikan satu satuan pada liquidity dan variabel independen yang lain konstan, maka debt to total equity akan turun 0,067878 sebesar satuan.

\section{Hasil Pengujian}

Tabel 4.1

Ringkasan Probabilitas dan Hasil Pengujian Hipotesis

\begin{tabular}{lll}
\hline Variabel & Probabilitas & H0 \\
\hline Bersama-sama (Uji-F) & 0,031114 & Ditolak \\
Return on Asset (Uji-t) & 0,0159 & Ditolak \\
Firm Size (Uji-t) & 0,7251 & Tidak ditolak \\
Asset Growth (Uji-t) & 0,4482 & Tidak ditolak \\
Liquidity (Uji-t) & 0,1452 & Tidak ditolak \\
\hline
\end{tabular}

\section{Uji hipotesis dengan Uji-F (bersama-sama)}

Dengan uji-F (bersama-sama) diketahui bahwa pengaruh profitability (return on asset), firm size (In asset), growth (asset growth), dan liquidity (current asset) bersama-sama mempengaruhi secara signifikan capital structure dengan hasil signifikansi sebesar 0,031114 dengan tingakat keyakinan 95\%

Uji Hipotesis 2 Profitability (return on asset) mempengaruhi capital structure

Variabel pada penelitian ini, yaitu profitability (return on asset) secara signifikan mempengaruhi capital structure dengan hasil signifikansi sebesar 0,0159 dengan tingkat keyakinan $95 \%$.

\section{Uji Hipotesis 3 Firm size (ln asset) mempengaruhi capital structure}

Hasil pada penelitian ini menunjukkan bahwa firm size (ln asset) secara tidak signifikan mempengaruhi capital structure dengan hasil signifikansi sebesar 0,7251 dengan tingkat keyakinan $95 \%$.

Uji Hipotesis 4 Growth (asset growth) mempengaruhi capital structure

Growth (asset growth) pada penelitian ini secara tidak signifikan mempengaruhi capital structure dengan tingkat signifikansi sebesar 0,4482 dengan tingkat keyakinan $95 \%$.

Uji Hipotesis 5 Liquidity (current ratio) mempengaruhi capital structure

Variabel kelima pada penelitian ini, yaitu liquidity (current ratio) secara tidak signifikan mempengaruhi capital structure dengan signifikansi sebesar 0,1452 dengan tingkat keyakinan sebesar $95 \%$.

Nilai $\mathbf{R}^{2}$ (Koefisien Determinasi) 
Nilai $\mathrm{R}^{2}$ (koefisien determinasi) digunakan untuk mengetahui besarnya kontribusi (pengaruh) yang diberikan oleh variabel independen $(\mathrm{X})$ terhadap variabel dependen (Y).

Tabel 4.1

Koefisien Determinasi $\left(\mathbf{R}^{2}\right)$

\begin{tabular}{|c|c|}
\hline & Adjusted R $^{2}$ \\
\hline Periode 2008-2015 & 0,105562 \\
\hline
\end{tabular}

Persamaan regresi linier ganda memiliki koefisien determinasi sebesar 10,56\% yang artinya sebesar $10,56 \%$ variabel dependen (capital structure) dapat dijelaskan oleh variabel independen, yaitu profitability (return on asset), firm size (ln asset), growth (asset growth), dan liquidity, sedangkan sisanya sebesar 89,44\% dapat dijelaskan oleh faktor-faktor lainnya, antara lain operating leverage, volatality, kondisi pasar, tangible assets, stabilitas penjualan, dan lain-lain.

\section{Pembahasan}

Dari hasil penelitian diatas, dapat disimpulkan bahwa return on asset (ROA) membantu perusahaan untuk mengurangi pemakain utang dalam sistem pendanaannya dan hal ini konsisten dengan teori pecking order yang menyatakan bahwa perusahaan dalam memenuhi kebutuhan pendanaan aset akan menggunakan sumber dana internalnya terlebih dahulu baru kemudian menggunakan sumber dana eksternal seperti pinjaman (utang) dan modal sendiri (ekuitas). Sama halnya dengan ukuran perusahaan. Perusahaan makanan dan minuman yang menjadi subjek penelitian ini merupakan perusahaan yang berukuran besar sehingga dalam pendanaan untuk kebutuhan asetnya lebih cenderung pendanaannya berasal dari internal perusahaan, akan tetapi apabila sumber internal tidak cukup memenuhi kebutuhan maka salah satu pemenuhan dana yang pendanaan berasal dari eksternal perusahaan (utang dan ekuitas) hal ini sesuai atau konsisten dengan teori pecking order. Perusahaan makanan dan minuman memiliki potensi pertumbuhan asset yang besar, oleh sebab itu utang perusahaan cenderung meningkatkan yang menyebabkan growth memiliki pengaruh positif terhadap capital structure perusahaan makanan dan minuman secara tidak signifikan. Likuiditas pada penelitian ini menggunakan current ratio yang hanya melihat dari asset jangka pendek dan utang jangka pendek, sehingga hasil yang didapatkan liquidity memiliki pengaruh tetapi tidak signifikan.

\section{DAFTAR PUSTAKA}

Brealey, Richard A., Myers, Stewart C., dan Marcus, Alan J. (2007). Dasar-dasar manajemen keuangan perusahaan. Jilid 2. Edisi ke-5. Jakarta: Erlangga

Brigham, Eugene., dan Houston, Joel F. (2009). Fundamentals of financial management. Edisi 12. New York: South-Western Cengage Learning

Gitman, Lawrence J., dan Zutter, Chad J. (2012). Principles of managerial finance. Edisi ke-13. Harlow, Essex: Pearson Education Limited

Ismiyanti, Fitri., dan Armansyah, Rohmad F. (2010). Motif go public, herding, ukuran perusahaan dan underpricing pada pasar modal indonesia. Jurnal Manajemen Teori dan Terapan Tahun ke 3 No 1

Loof, Hans. (2003). Dynamic optimal capital structure and technological change. Discussion Paper Centre for European Economic Research No 03-06 
Margaretha, Farah. (2007). Manajemen keuangan bagi industri jasa. Jakarta: Grasindo

Margaretha, Farah., dan Ramadhan, Rizky A. (2010). Faktor-faktor yang mempengaruhi struktur modal pada industri manufaktur di bursa efek indonesia. Jurnal Bisnis dan Akutansi Volume 12 No 2. Hal 119-130

Nishioka, Shinichi., dan Baba, Naohiko. (2004). Dynamic capital structure of japanese firms : how far has the reduction of excess leverage. Bank of Japan Working Paper Series No 4. Edisi 16

Seftianne, dan Handayani, Ratih. (2011). Faktor-faktor yang mempengaruhi struktur modal pada perusahaan publik sektor manufaktur. Jurnal Bisnis dan Akutansi. Volume 13. No. 1. Hal 39-56

Sunder, Lakshmi Shyam., dan Myers, Stewart C. (1994). Testing static tradeoff against pecking order models of capital structure. Journal of Financial Economics 51. Hal 219-244

Titman, Sheridan., dan Wessels, Roberto. (1988). The determinants of capital structure choice. The Journal of Finance. Volume 43 No 1. Hal 1-19

Weston, J. Fred, dan Brigham, Eugene F. (1993). Essentials of managerial finance. Edisi 10. USA: Harcourt Brace College Publisher. 
